\title{
Assessment of the changes in some diagnostic parameters in male albino rats (Rattus norvegicus) toxicated with thiodicarb insecticide
}

\author{
Mohammed Salah Ab. Ab. AL-Shinnawy \\ Biological and Geological Sciences Department, Faculty of Education, Ain Shams University, \\ Cairo, Egypt.
}

\section{ABSTRACT}

The Present work investigates the serum levels of glucose, cholesterol, protein, urea, creatinine and some enzyme activities (AST,ALT and ALP) in male albino rats treated orally with 1/10 LD50 dose of thiodicarb insecticide (carbamate group)daily for 7 days (short-term) and 30days (long-term).

A highly significant elevation in serum urea, creatinine, AST and ALT accompanied by a highly significant decrease in the body weight and a significant increase in serum glucose level were recorded in rats of long-term group. While, the short-term group showed a highly significant increase in serum level of glucose and urea. Moreover, a significant decrease in serum cholesterol content was recorded but the total protein concentration and ALP activity were not affected.

Keywords: Thiodicarb, carbamate, serum, insecticide, and albino rats.

\section{INTRODUCTION}

Carbamates are widely used in industry, agriculture and public health purposes. They were detected in well water and certain plants (Abdel-Rahman et al.,1985).Insecticides, even in very low concentrations, have been reported to interfere with basal metabolism (Sanders et al.,1974; Vigro and Bellward, 1975 and Write et al., 1977).

Carbamate pesticides are among the most toxic compounds employed for insect control. The need for a complete assessment of their potential toxicological hazards to man has assumed greater importance.

On the other hand, the extensive use of insecticides to control agricultural pests has caused a great concern because of the possible effects of these compounds on human being as well as wild and domestic animals (Ezzat et al., 1991) and (Alpalan et al., 2006). Thiodicarb is a highly effective oxime carbamate insecticide that has produced outstanding control of many pests of agricultural crops. Major features of this product include long residual activity (Hernandez et al., 2006). The objective of this study is assessment a correlation between different biochemical parameters and the treatment by thiodicarb.

\section{MATERIALS AND METHODS}

Forty mature male albino rats (Rattus norvegicus) ranging in weight from 80100 gm., were essentially obtained from Schistosoma Biological Supply Program Theodor Bilharz Research Institute. Each two rats were placed in metal cage. They were kept under suitable care before experimentation in clean laboratory conditions, fed on standard diet of compact chops which was obtained from AgriculturalIntegration Company, Giza-Egypt. In addition of milk and water ad-Libitum. They 
kept under these normal conditions till they ranged in weight from $100-120 \mathrm{gm}$. before starting the experiment. The rats were allocated at random into 4 equal groups 10 rats each. Rats in group A were considered as controls for 7 days (short-term). Rats in group B were treated orally with a dose equal 1/10 LD 50 of thiodicarb insecticide daily for 7days. Rats in group $\mathrm{C}$ were considered as controls for 30 days (long-term).

Rats in group $\mathrm{D}$ were treated orally with a dose equal $1 / 10 \mathrm{LD} 5 \mathrm{O}$ of thiodicarb insecticide daily for 30 days.

All of the control and treated animals were individually weighed in order to detect any change that may take place in their body weights. The percentage of body weight gain was calculated as follows:

$\frac{\text { Mean final weight }- \text { Mean initial weight }}{\text { Mean initial body weight }} \times 100$

\section{Biochemical Studies:}

At the end of experimental periods, individual samples were then collected after18h. Fast from the different groups. Samples of blood withdrawn and left to clot in a clean dry test tube for each animal, then centrifuged at $3000 \mathrm{rpm}$ for ten minutes.

Part of the clear supernatant serum was used immediately for glucose determination. The remain serum was frozen at-20C for the subsequent analysis.

Serum glucose level was measured according to the "enzymatic colorimetric" method described by Trinder (1969). The total cholesterol was carried out according to Allain et al., (1974). Serum total protein was estimated according to the method described by Domas (1975). Urea was determined according to the method described by Patton and Crouch (1977). Creatinine was measured according to "kinetic" method described by Bartels and Bohmer (1972). Serum aspartate transaminase (AST) and alanine transaminase (ALT) activities were carried out according to Reitman and Frankel (1957). Serum alkaline phosphatase (ALP) was determined by the method of Kind and King (1954).

\section{Data analysis:}

Biological data resulted in the present study were computed and analysed statistically according to the mathematical principles of handling frequency distributions by Compbell (1974).

\section{RESULTS}

The effects of repeated doses of thiodicarb insecticide on body weights (gain or loss) of the rats were recorded in Table (1) and Figure (1).The findings indicated that treated rats showed highly significant $(\mathrm{P}<0.001)$ decreases in their body weights after feeding for 30days as compared with control group (=-14.96\% decrease), while the body weight was not obviously changed on the other tested period (7days).

Table (1): Effect of thiodicarb insecticide on body weight (gain or loss gm.) of male albino rats.

\begin{tabular}{|c|c|c|c|c|}
\hline \multirow{2}{*}{} & \multicolumn{2}{|c|}{ Long - term } & \multicolumn{2}{c|}{ Short - term } \\
\cline { 2 - 5 } & control & treated & control & treated \\
\hline Mean \pm S.D. & 5.99 & 5.23 & 18.58 & 15.80 \\
& \pm 0.87 & \pm 1.07 & \pm 0.59 & \pm 0.49 \\
\hline \% of change & \multicolumn{2}{|c|}{-12.69} & \multicolumn{2}{c|}{$\mathrm{P}>0.001 * * *$} \\
\hline P value & \multicolumn{2}{|c|}{$\mathrm{P}>0.05 *$} & $* * *$ Highly Significant \\
\hline
\end{tabular}




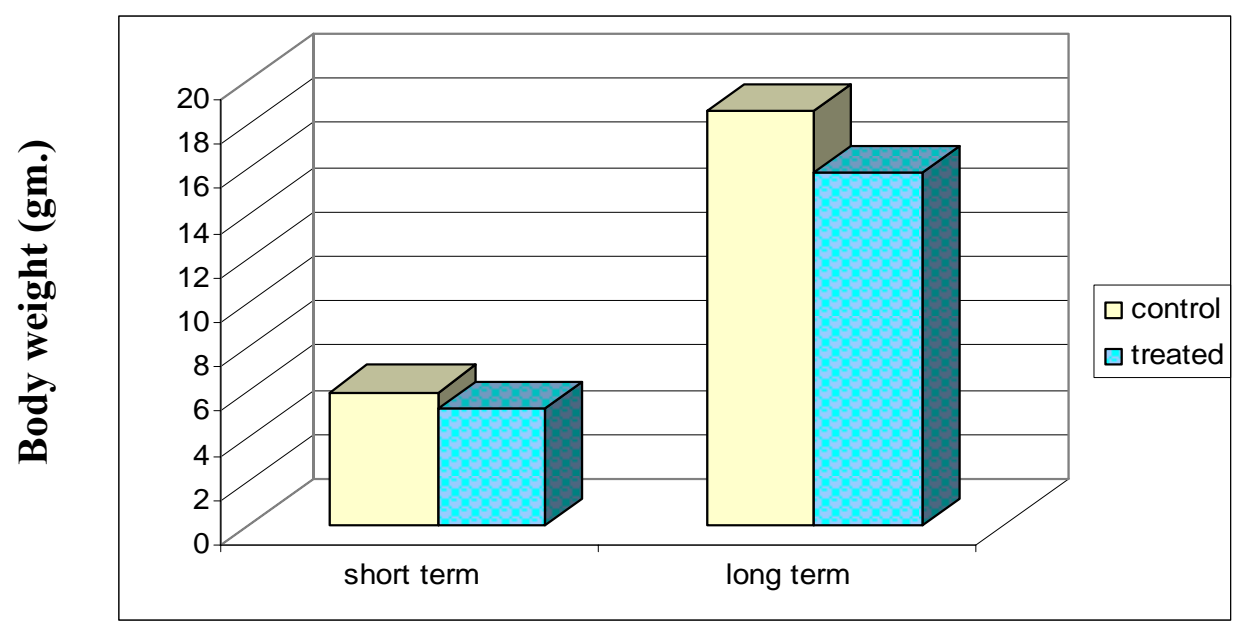

Fig. (1): chart illustration of thiodicarb insecticide compared with that of control effect on body weight (gain or loss gm.) of male albino rats.

The data represented in Table (2) and Figure (2) displayed the effect of thiodicarb on serum glucose level, total cholesterol and protein content. The glucose levels of treated animal groups recorded an elevation. It was highly significant $(\mathrm{P}<0.001)$ in short-term treated group $(=+20.14 \%$ increase $)$, and significant $(\mathrm{P}<0.05)$ in long-term treated group $(=+12.45 \%$ increase $)$. While serum content of total cholesterol was significantly $(\mathrm{P}<0.05)$ decreased in the two treated groups $(=-3.85 \%$,$3.81 \%$ decrease), but serum protein was not effected at any period of the experiment.

Table (2): Effect of thiodicarb insecticide on glucose level $(\mathrm{mg} / 100 \mathrm{ml}) ;$ total cholesterol content $(\mathrm{mg} / \mathrm{dl})$ and total protein content $(\mathrm{gm} / \mathrm{dl})$ compared with that of control in male albino rat serum.

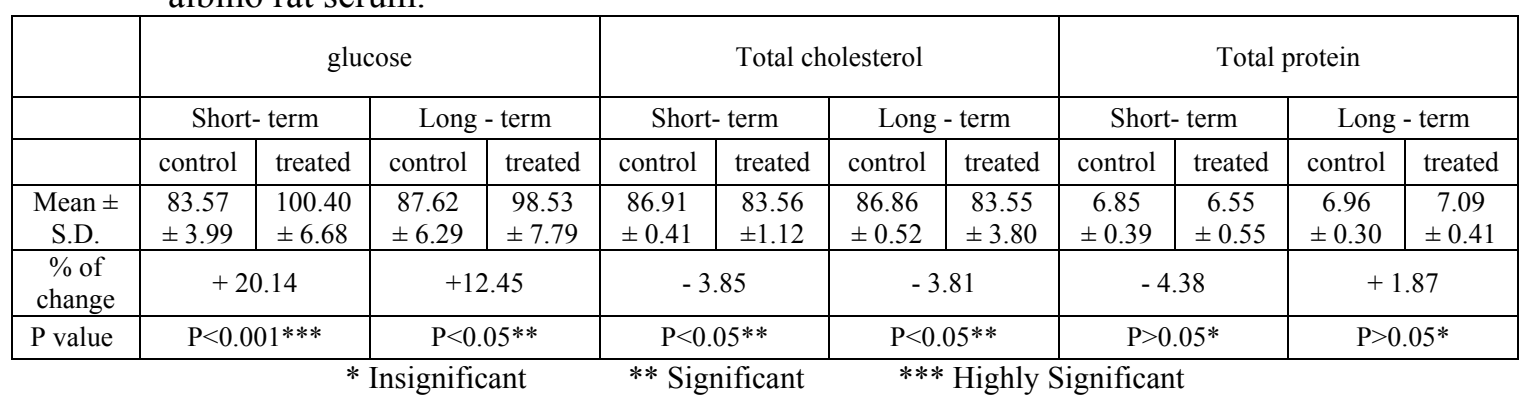



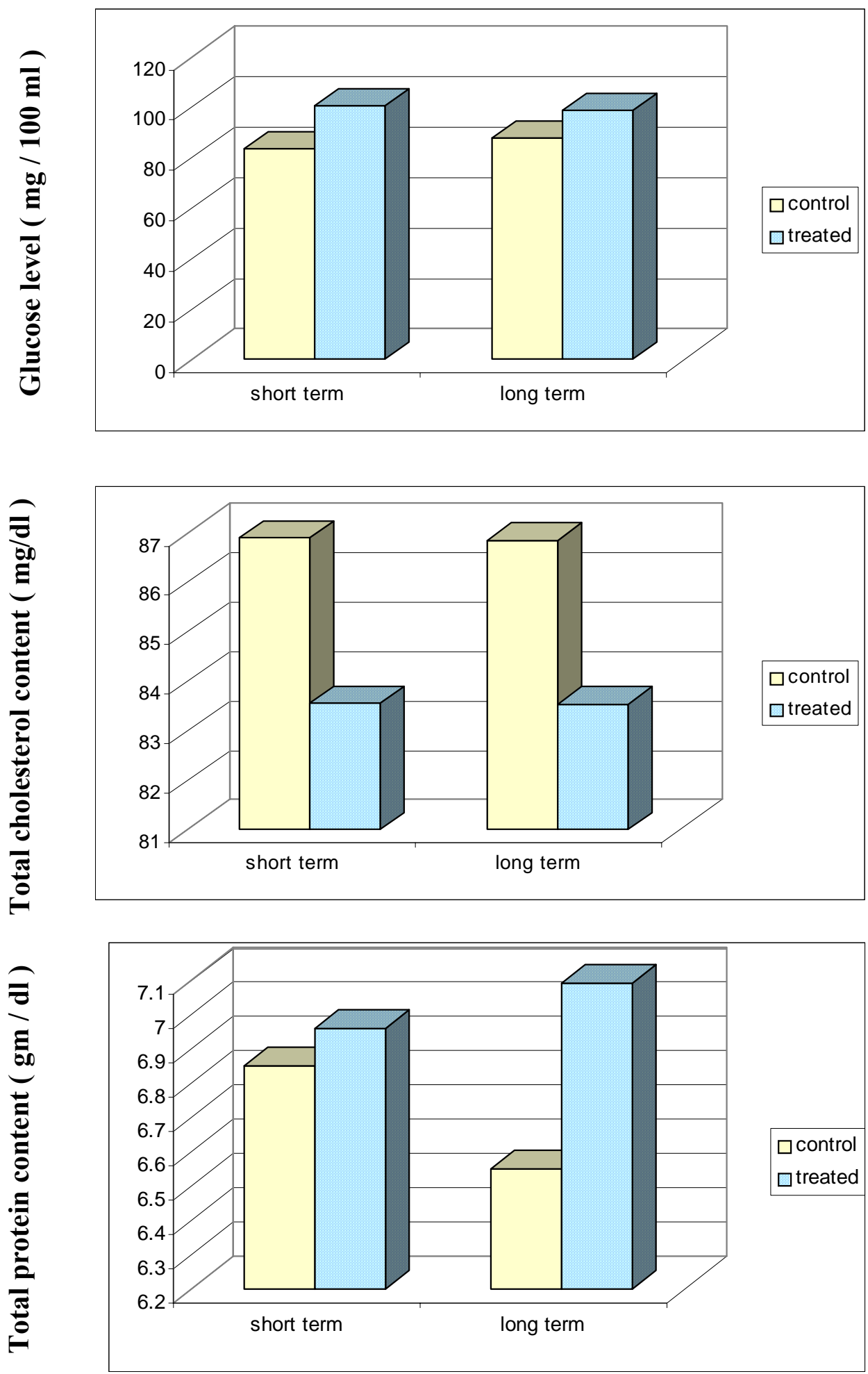

\section{Histogram profile}

Fig. (2): Effect of thiodicarb insecticide on glucose level $(\mathrm{mg} / 100 \mathrm{ml})$; total cholesterol content $(\mathrm{mg} / \mathrm{dl})$ and total protein content $(\mathrm{gm} / \mathrm{dl})$ compared with that of control in male albino rat serum . 
The obtained data in Table (3) as a short and long-term administration of thiodicarb showed a highly significant $(\mathrm{P}<0.001)$ raise of rat serum urea $(=+30.69 \%$ $+75.98 \%$ increase $)$. Serum creatinine content was highly significant $(\mathrm{P}<0.001)$ elevated above the control values $(=+27.07 \%$ increase) after 30 days in response to the thiodicarb treatment.

Table (3): Effect of thiodicarb insecticide on urea content(mg/l)and creatinine content(mg/l) comparing with the control in male albino rat serum.

\begin{tabular}{|c|c|c|c|c|c|c|c|c|}
\hline & \multicolumn{4}{|c|}{ urea } & \multicolumn{4}{|c|}{ creatinine } \\
\hline & \multicolumn{2}{|c|}{ Short- term } & \multicolumn{2}{|c|}{ Long - term } & \multicolumn{2}{|c|}{ Short- term } & \multicolumn{2}{|c|}{ Long - term } \\
\hline & control & treated & control & treated & control & treated & control & treated \\
\hline Mean \pm S.D. & $\begin{array}{r}33.82 \\
\pm 1.79 \\
\end{array}$ & $\begin{array}{r}44.20 \\
\pm 3.18 \\
\end{array}$ & $\begin{array}{r}31.72 \\
\pm 3.83 \\
\end{array}$ & $\begin{array}{c}55.82 \\
\pm 3.24 \\
\end{array}$ & $\begin{array}{r}11.84 \\
\pm 1.33 \\
\end{array}$ & $\begin{array}{r}11.07 \\
\pm 0.91 \\
\end{array}$ & $\begin{array}{c}14.22 \\
\pm 1.48 \\
\end{array}$ & $\begin{array}{r}18.07 \\
\pm 1.62 \\
\end{array}$ \\
\hline$\%$ of change & \multicolumn{2}{|c|}{+30.69} & \multicolumn{2}{|c|}{+75.98} & \multicolumn{2}{|c|}{-6.50} & \multicolumn{2}{|c|}{+27.07} \\
\hline$P$ value & \multicolumn{2}{|c|}{$\mathrm{P}<0.001 * * *$} & \multicolumn{2}{|c|}{$\mathrm{P}<0.001 * * *$} & \multicolumn{2}{|c|}{$\mathrm{P}>0.05^{*}$} & \multicolumn{2}{|c|}{$\mathrm{P}<0.001 * * *$} \\
\hline 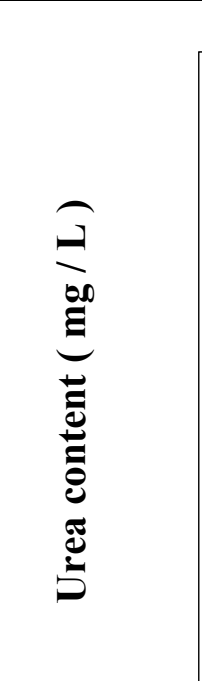 & $\begin{array}{l}60 \\
50 \\
40 \\
30 \\
20 \\
10\end{array}$ & tificant & & $* x$ & Highly & nifican & $\begin{array}{l}\square \text { control } \\
\square \text { treated }\end{array}$ & \\
\hline
\end{tabular}

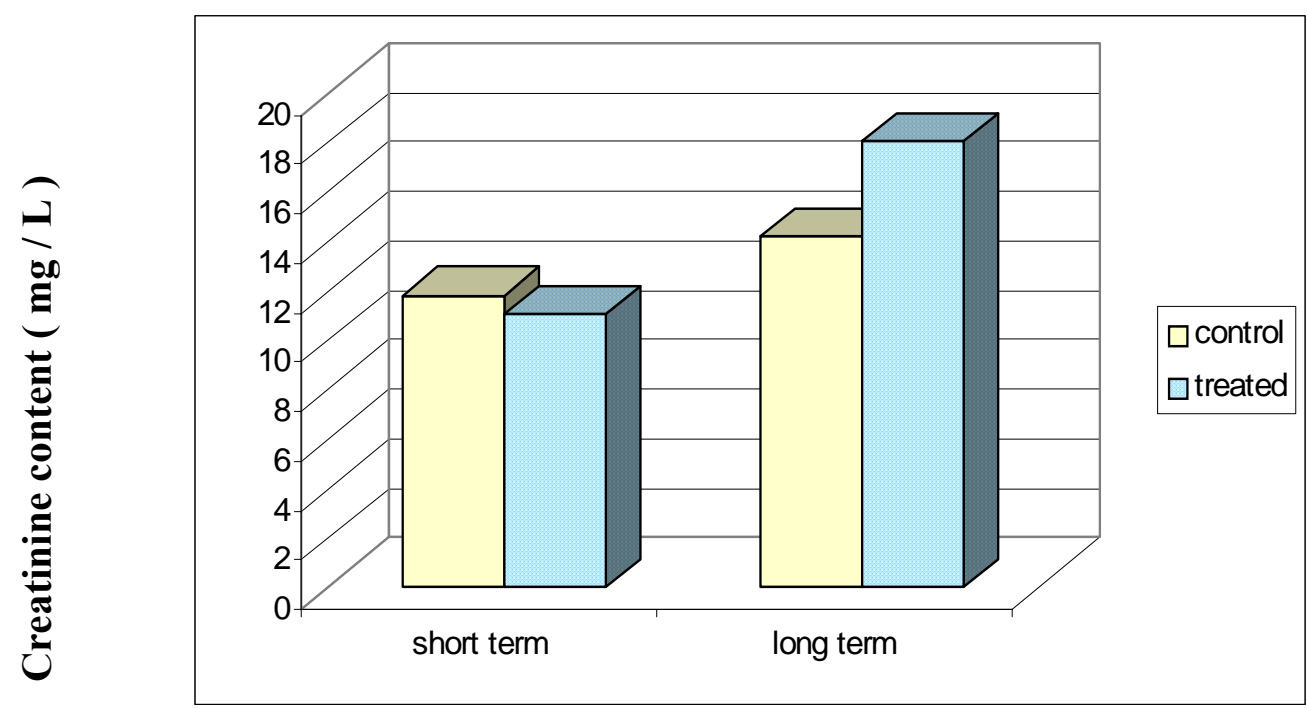

Fig (3): Effect of thiodicarb insecticide on urea content (mg / L) and creatinine content (mg / L) compared with that of control in male albino rat serum. 
The data represented in Table (4) and Figure (4) showed that there are no changes in activities of AST, ALT and ALP in all rats of short-term treated group. But rats of long-term treated group, the transaminases (AST, ALT) activities recorded a highly significant $(\mathrm{P}<0.001)$ increase.

Table(4): Effect of thiodicarb insecticide on AST , ALT and ALP activities (U/ml) expressed as percent change from control in male albino rat serum.

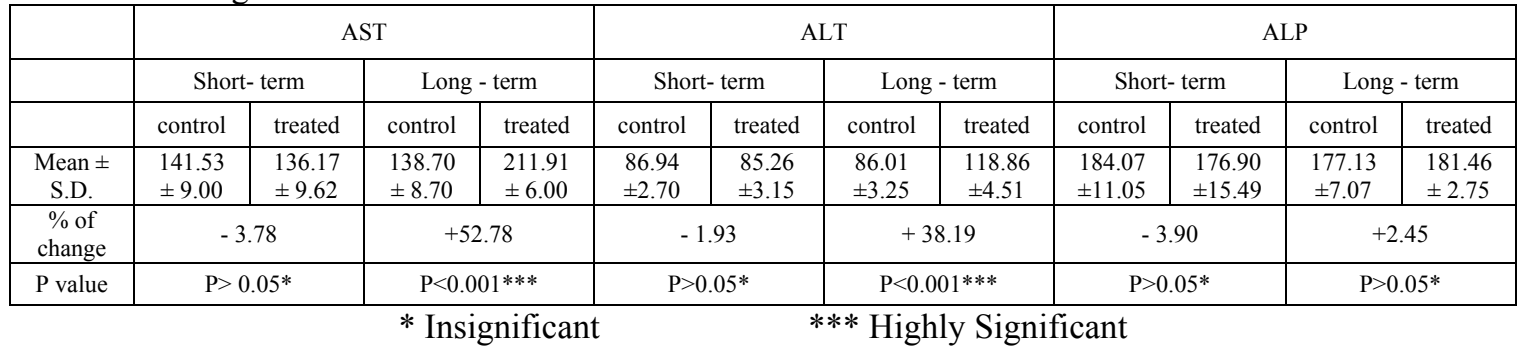
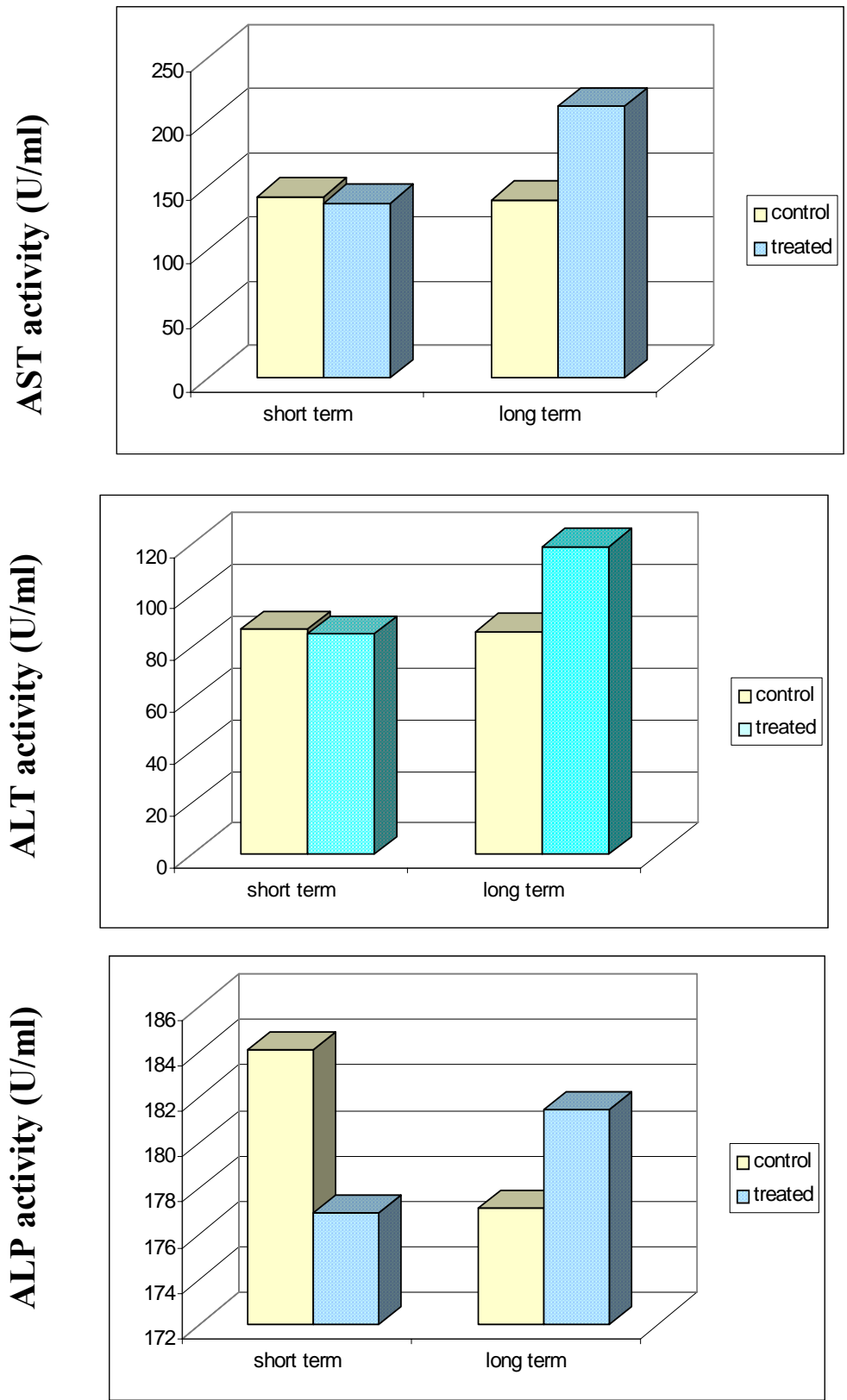

Fig (4): Effect of thiodicarb insecticide on AST, ALT and ALP activities (U/ml ) compared with the control in male albino rat serum. 


\section{DISCUSSION}

The intensive use of pesticides to eliminate pests or to regulate crop growth led to pesticide residues in soil, air, water, stored grains, crops and plants at concentration levels which exceed the legal limits(Süsse and Müler,1996).The great hazards caused by pesticides on the live stocks are due to their accidental exposure to these pesticides either by ingestion or inhalation (Yamanaka et al.,1996; Hernandez et al., 2006 and Gokhan et al., 2008). Therefore, it was decided to perform this investigation to determine more clearly, the influence of these insecticides on male albino rats.

The present study revealed that only those rats fed on thiodicarb showed highly significant decreases in their body weights after toxication for 30 days. This decrease may probably attributed to the loss of appetite, lesser food intake and/or metabolic disturbance caused by thiodicarb treatment. These results are in harmony with those obtained by Dikdshith et al.,1991 ; Badawy et al., 1992 ; Paul et al.,1993; Abd El-Hady and Abdeen,1997.Also, the loss of body weight may be due to diarrhea, diabetes and decreased nucleic acid contents (Rashwan et al.,1994).

In the present investigation high level of serum glucose were recorded in all groups of thiodicarb toxicated rats. These results are in good agreement with those findings obtained by Areechon and Plumb (1990); Thaker and Garg (1993); Kumar et al., (1996); Gade (2000) and Fouda (2004).

The hyperglycemia observed in the present work may be due to thiodicarb administration enhance the activities of the enzymes involved in gluconeogenesis leading to formation of glucose from non-carbohydrate source (Evans, 1996).

The weight loss encountered in this study may be a consequence to thiodicarb which appears to have a hypocholesterolemic effect as revealed by a decrease in total serum cholesterol content of the corresponding rat groups. These results are supported by the findings of Shakoori et al., (1988) and Saleh (1990). While the serum total protein in this study was not clearly affected at the two periods, this result is in accordance to Fayez and Kilgore (1992).

The present investigation showed a highly significant increase in serum urea content of all toxicaded rats. These results are in accordance with those of Abu-ELZahab et al., (1993); Abdel-Baky (1999); Gad (2000) and Khan et al.,(2008).

Creatinine is a waste product of creatine metabolism whose measurement provides an exceptionally useful index of kidney function. The level of serum creatinine in group D showed a highly significant increase.Similar observations of raised serum creatinine level were reported by Al-Sahhaf (1995); Yousef et al., (2003); Fouda (2004) and Khan et al.,(2008).

Serum transaminases (AST,ALT) activity are known as toxicity markers in the study of hepatotoxicity by chemicals (Govindwar and Dalvi,1990). An increase in the activities of these enzymes is termed as the early recognition of toxic hepatitis.

A highly significant increase in these enzyme activities was observed at longterm period of treated group, indicating liver damage. Similar results were reported by Abdel Mageed et al., (2001); Fouda and Azab (2003); El-Shater (2003); Khan et al.,(2008) and Jyotsna et al., (2008). The authors indicated that insecticides caused an increase in serum AST and ALT activities in several species of animals.

Finally, it would be concluded that countries should use all publicity media to inform the public, the safe use of insecticides. Thus the use of insecticides in farms or houses must be under strict measures. 


\section{REFERENCES}

Abdel-Baky, S. M. (1999). Toxicological studies on fenitrothion in white rats special reference to its residues. Ph. D. Thesis, Dep. of Forensic Medicine and Toxicology, Fac. Vet. Med., Suez Canal University.

Abdel-Hady, E. K. and Abdeen, A. M. (1997). Biochemical and histopathological Observations on the influence of dimethoate and nuvacron insecticides on pregnant rats and their newborn. J. Union Arab Biol., 7(A): 75-107.

Abdel-Mageed, F. A.; Nessiem, A. L. and Nour EL-Dien, S. M. (2001): Biochemical studies on the interactions of certain xenobiotics with metronidazole in rats. J. Egypt. Ger. Soc. Zool., 34(A): 245-254.

Abdel-Rahman,M. S.; Waldron, L. D. and Klein, K. M. (1985):Combination effect of carbaryl and malathion in rats.Arch.Environ.Contam.Toxicol.14(4):459464.

Abu-EL-Zahab, H. S. H.; Amr, M. M.; Abdel-Aal, W. E.; Awadallah, R. and Elkhyat, Z. A. M. (1993). Physiological and histopathological studies on long-term inhalation of adult albino rats to pyrethroids. J. Egypt. Ger. Soc. Zool., 11(C):275-297.

Allain, C. C.; Poon, L. S.; Chan, C. S. G.; Richmond, W. and Fu, P. C. (1974). Enzymatic determination of total serum cholesterol .Clin.Chem.20,470.

Alpalan, G.; Kanat, Hilmi, D.; Dilek, B. and Altuntas, I. (2006). Effects of diazinon at different doses on rat liver and pancreas tissues. Depart. of Biochem. Suleyman Demirel Univ. Sch. of Med. Isparta. Turk. pest. Biochem. and Physiol.,

$$
\text { 87(2):103-108. }
$$

Al-Sahhaf, Z. Y. (1995). Haematological changes induced by a carbamate insecticide lannate in the toad. J. Egypt. Ger. Soc. Zool., 18(A):89-102.

Areechon, N. and Plumb, J. A. (1990). Sublethal effects of malathion on channel catfish Ictalurus punctatus. Bull. of environ. Contam. Toxicol., 44(3): 435442 .

Badawy, M. E.; Amer, T. A.; Ibrahim, H. A. and El-Sawi, M. R. (1992). Curacron toxicity in relation to some physical and biochemical parameters in rat. J. Egypt. Ger. Soc. Zool., 8(A):101-119.

Bartels, H. and Bohmer, M. (1972). Kinetic determination of creatinine concentration. Clin. Chem. Acta., 37-193.

Compbell, R. C. (1974). Statistics for Biologists. 2nd ed. Cambridge Univ. Press, Cambridge, England.

Diskshith, T. S. S.; Raizada, R. B. and Srivastava, M. K. (1991). Long-term dietary study and development of no observed effect level of technical $\mathrm{HCH}$ to rats. J. Toxicol. Environ. Health, 34(1): 495-507.

Domas, B. T. (1975). Standards for total serum protein assays. A collaborative study. Clinical Chemistry, 21:1159-1166.

El-Shater, A. A. (2003). Effects of the organophosphorus Insecticide parathion on the secretory activity of the thyroid gland and on some biochemical and haematological parameters of adult male rats. J. Egypt. Ger. Soc .Zool., 40(A):447-456.

Evans, O. G. (1996). Animal clinical chemistry. Aprimer for toxicologists 1st Ed., pp. 73-98.

Ezzat, A. R.; Saleh, F.; El-Saify, A. A. and El-Shater, A. A. (1991). Thyroid function and lipid metabolism in pigeon treated with insecticides acetellic and cypermethrin. J. Egypt Ger. Soc. Zool., 3:75-84. 
Fayez, V. and Kilgore, W. (1992). Acute toxic effects of oxamyl in rats. Fundam Appl., Toxicol; 18(1):155-9.

Fouda, F. M. and Azab, A. M. (2003). A comparative toxicological study on the effects of chemical and biological pesticides on the liver of Nile catfish, Clarias gariepinus. J. Egypt. Ger. Soc. Zool., 40(A):105-120.

Fouda, F. M. (2004). Haematological and biochemical studies on the effects of a biological and chemical pesticides on the Nile Catfish, Clarias gariepinus. J. Egypt. Ger. Soc. Zool., 43(A):77-97.

Gad, O. E. A. (2000). Toxicological studies on some pesticides with special reference to its cytogenetic effect. Ph. D. Thesis, Department of Forensic Medicine and Toxicology, Faculty of Veterinary Medicine, Suez Canal University.

Gokhan, E.; Kanbur, M.; Silici, S.; Liman, B. C.; Altinordulu, S. and Sarica, Z. S. (2008). Effects of carbaryl on some biochemical changes in rats. Food and Chem. Toxicol. Environ, Res., 14,(1), Turkey.

Govindwar, S. P. and Dalvi, R. R. (1990). Age dependent Toxicity of a corn extract in young and old male rats. Vet. Hum. Toxicol; 32:23-6.

Hernandz, F. A.; Gomez, M. A.; Perez, V. G.; lario, V. J., Pena, G.; Gill, F.; lopez, O.; Rodrig, L.; Pion, G. and Pla, A. (2006). Influence of exposure to pesticides on serum components and enzyme activities of cytotoxicity among intensive agricultural farmers. Environ. Reas. J. 102:70-76.

Jyotsna, A. P.; Arum, J. P.; Ajit, V. S.; Sanjay, P. and Govindwar, S. P. (2008). Effect of methomyl on hepatic mixed function oxidases in rats. Indian J. of Pharmacol. 40 (4): 158-163.

Khan D. A.; Bhatti, M. M.; Khan, F. A.; Naqvi, S. T. and Karam, A. (2008). Adverse effects of Pesticides residues on biochemical markers in Pakistani Tobacco farmers. Int. J. Clin. Exp. Med.1(3):274-282.

Kind, P. R. N. and King, E. J. (1954). Determination of alkaline phosphatase activity in serum. J. Clin. Pathol.,7:322-327.

Kumar, H. ; Gupta, A. B. and Srivastave, A. K.(1996). Physiological responses of a freshwater telecast Heteropneustes fossilis (Bloch) to an organophosphorus insecticide (metasystox).Flora and Fauna J., 2(1): 65-67.

Patton, C. J. and Crouch, S. R. (1977). Enzymatic determination of urea concentration in: Anal.Chem.49:464-469.

Paul, V.; Sheela, S. ; Balsubramaniam, E. and Zaki, M. (1993). Behavioral and biochemical changes produced by repeated oral administration of insecticide endosulfan in immature rats. Indian. J. Physiol. Pharmacol. 37(3):204-208.

Rashwan, S.; Khalil, H.; Abd El-Kader, H.; Abd El-Raouf, S. and Zaghloul, S. (1994). Histological, ultrastructurcural and histochemical study on the effect of dexamethasone on the liver of rat. Sci. Conf. Egypt. Soc. Hist. Cyt. ,Fac. Med., Cairo Univ.

Reitman,S. and Frankel, S. (1957). A colourimetric method for the determination of serum glutamic oxaloacetic and glutamic pyruvic transaminases. Am. J. Clin. Path. 28:56-63.

Saleh, F. (1990). Metabolic effects of carbamate insecticide (methomyl) on rats. III: Changes in some blood biochemical indices in the rats poisoned with the insecticide. Egypt J. Physiol. Sci., 14(1-2):65-74.

Sanders, O. T.; Zepp, R. I. and Kirk Patrick, R. L. (1974). Effect of PCP ingestion on sleeping times, organ weights, food consumption, serum conrticosterone and survival of albino mice. Bull. Environ.Contam.Toxiol.,12:394-399. 
Shakoori, A. R.; Ali, S. S. and Saleem, M. A. (1988). Effect of six months feeding of cypermethrin on the blood and liver of albino rats. J. Biochem .Toxicol., 3:59-72.

Süsse, H. and Müller, H. (1996). Pesticide analysis by micellar electrokinetic capillary chromatography. J. chromatography. A., 730:337-343.

Thaker, A. M. and Garg, B. D. (1993). Biochemical alterations in chicks following long term exposure to endosulfan and malathion. Ind. J. of poultry, Sci., 28(1):51-55.

Trinder, P. (1969). Determination of glucose in blood using glucose oxidase with an alternative acceptor. Ann. Clin. Biochem., 6:24-27.

Vigro, B. B.and Bellward, G. D. (1975). Effect of dietary dieldrin on the liver and drug metabolism in the female Swiss - Vancouvre mouse. Can. J. Physiol. Pharmacol., 53:903-911.

Write, A. S.; Akintonwa, D. A. A. and Wooter, M. F. (1977). Studies on the interaction of dieldrin with mammalian liver cells at the subcellular level. Ecotoxicol. Environ. Saf., 1:7-16.

Yamanaka, S.; Ohta, K. I.; Tomito, Y.; Tokayanagi, A.; Nomara, T. and Takaesu, Y. (1996). Effect of acute organophosphorus poisoning in rats aging and solubility of organophasphates. Environ. Health Prev. Med, 1(3):119-127.

Yousef, M. I.; EL-demerdash, F. M.; Kamel, K. I. and Al-Salheen, K. S. (2003). Changes in some haematological and biochemical indices of rabbits induced by isoflavones and cypermethrin. J. Toxical., 189 (3):223-234.

\section{ARABIC SUMMERY}

$$
\begin{aligned}
& \text { تقييم تغيرات بعض المعايير التشخيصية فى ذكور الجرذان البيضاء (راتس نورفيجيكس) المسممة }
\end{aligned}
$$

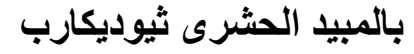

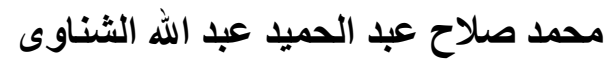

$$
\begin{aligned}
& \text { قسم العلوم البيولوجية و الجيولوجية ـ كلية التربية ـ جامعة عيد الهين شمس- مصر ـ القاهرة } \\
& \text { يهدف البحث إلى الكثف عن مستوى الجلوكوز ، الكوليستيرول و البروتين الكلى ومحتوى المصل }
\end{aligned}
$$

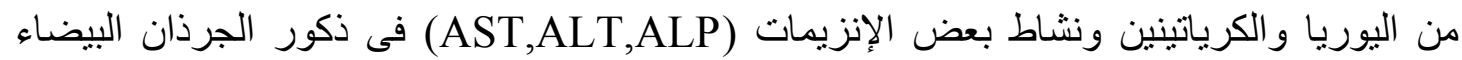

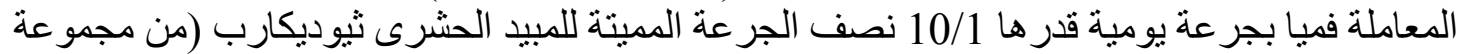

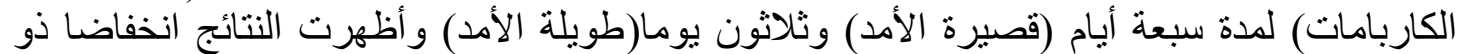

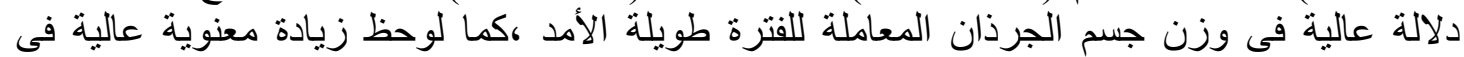

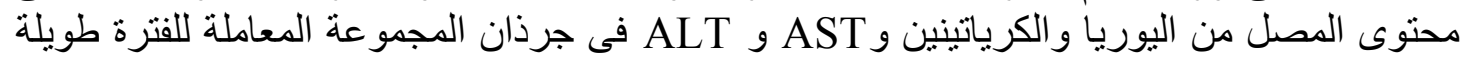

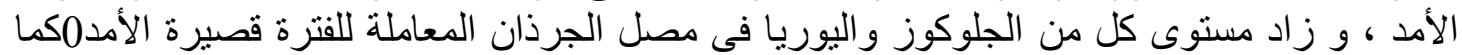

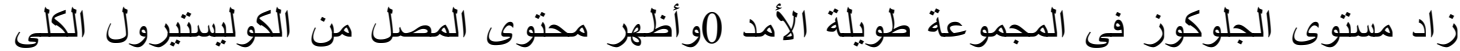

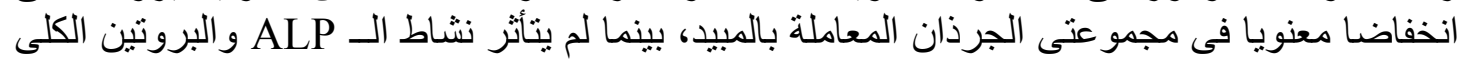

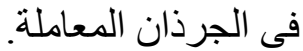

